\title{
11. Postnatal Development of Inhibitory Control and Sucking-Induced Activation of Pituitary Pars Intermedia in Infant Mice
}

\author{
A Morphometric Study \\ By Yasuo Kobayashi and Makoto Takeuchi \\ Department of Biology, Faculty of Science, Okayama University, \\ Tsushima, Okayama 700 \\ (Communicated by Kiyoshi TAKeWAKI, M. J. A., Jan. 12, 1985)
}

The hypothalamic inhibitory control over the pars intermedia of the pituitary was first noticed in the frog by Etkin (1962). It is now widely accepted that the inhibitory control of melanocyte-stimulating hormone (MSH) secretion is mediated by dopaminergic nerves originating in the arcuate nucleus of the hypothalamus in the rat (Björklund et al., 1973; Tilders et al., 1975) and the mouse (Björklund et al., 1968). Our previous studies have provided morphological evidence that the administration of a sodium-deficient diet (Kobayashi, 1974, 1977; Kobayashi and Takema, 1976) and experimental copious drinking (Kobayashi et al., 1984) elicited the secretory activity of the pars intermedia by impairing the inhibitory effects of the hypothalamus. However, these experimental conditions seem to be very seldom met with normally. If murines require an increase in MSH secretion during their life span, the inhibitory control of the pars intermedia would be attenuated with a resultant rise in MSH secretion, as in the processes of physiological color change of the frog. Studies on such relevant physiological condition (s) may be helpful to disclose the extrapigmentary role of the pars intermedia which is still poorly understood in mammals. The objectives of the present study were to determine the time of onset of postnatal development of inhibitory control over the pars intermedia and to explore the conditions under which the synthesis and release of the pars intermedia hormone are stimulated in infant mice.

Materials and methods. Mice of the ICR/JCL strain were used in all experiments. Litter size was adjusted to 8 shortly after birth. At $0,1,3$ and 7 days of age, 3 pups each under normal nursing conditions were sacrificed by decapitation. Three other infant mice at 7 days of age were isolated from their mother for $5 \mathrm{~h}$ and then returned to their mother for $1 \mathrm{~h}$ nursing before decapitation. Three other pups decapitated after $5 \mathrm{~h}$ separation without reunion with their mother served as controls. The pituitaries were fixed with glutaraldehyde and $\mathrm{OsO}_{4}$ and processed by routine methods for electron microscopy. Thin mid-sagittal sections of the pars intermedia were examined with an HU-11E electron microscope. Electron micrographs of pars intermedia cells (30-50 cells in each group) were used for morphometrical analysis at $\times 10,000$ enlargement as described previously (Kobayashi, 1974). Statistical analysis was performed using Student's t-test.

Results. 1) Postnatal development of the inhibitory control over the pars intermedia. The percent volume of the cytoplasm occupied by cisternae of rough endoplasmic reticulum (\% r-ER) showed an initial peak immediately after birth 
$(47.9 \%)$ followed by a significant fall on Day $3(36.0 \%)$ and a further decline on Day $7(17.7 \%)$ (Table I). Concomitant decrease in number of Golgi granules per unit Golgi area was obvious on Day 7(2.7-1.1). The numerical density of secretory granules remained unchanged for the first 3 days of postnatal life (1.7-1.6) and rose significantly on Day 7 (2.8) (Table I).

2) Changes in pars intermedia cells after sucking in mice at 7 days of age. Hypertrophy of pars intermedia cells took place in sucking pups reunited with their mother after transient separation as compared with the isolation controls. Accordingly, the \% r-ER and the numerical density of secretory granules were corrected in such a way that each cell size in sucking mice was reduced (by $20 \%$ ) to match the cell size of the two groups in average and the values were recalculated. The Golgi complex of pars intermedia cells in sucking mice was more extensive than in the isolation controls. The number of Golgi granules per unit

Table I. Percent volume of $\mathrm{r}-\mathrm{ER}$ and numerical density of Golgi granules and of secretory granules in pars intermedia cells from 0- to 7-day-old mice, and 7-day-old mice after isolation from their mother for $5 \mathrm{~h}$ and those returned to their mother for renewed sucking for $1 \mathrm{~h}$

\begin{tabular}{|c|c|c|c|c|}
\hline Age (day) & $\%$ r-ER & $\begin{array}{l}\text { Golgi granules } \\
\text { per } \mu \mathrm{m}^{2}\end{array}$ & $\begin{array}{l}\text { Secretory } \\
\text { per } \underset{\mu \mathrm{m}^{2}}{\operatorname{granu}}\end{array}$ & les \\
\hline 0 & $47.9 \pm 1.8$ & $2.7 \pm 0.4$ & $1.7 \pm 0.1$ & \\
\hline 1 & $45.1 \pm 1.6$ & $2.5 \pm 0.5$ & $1.6 \pm 0.3$ & \\
\hline 3 & $36.0 \pm 1.7^{*}$ & $2.3 \pm 0.3$ & $1.6 \pm 0.2$ & Significant \\
\hline 7 & $17.7 \pm 1.0^{* * *}$ & $1.1 \pm 0.1 \%$ & $2.8 \pm 0.1^{*}$ & vs. age 0 \\
\hline $\begin{array}{c}7 \\
\text { (isolation) }\end{array}$ & $19.5 \pm 1.5$ & $1.2 \pm 0.1$ & $2.9 \pm 0.1$ & $\begin{array}{l}\text { Significant } \\
\text { differences }\end{array}$ \\
\hline $\begin{array}{c}7 \\
\text { (sucking) }\end{array}$ & $42.0 \pm 1.5^{* * *}$ & $2.1 \pm 0.1^{* *}$ & $1.6 \pm 0.1^{* *}$ & vs. isolation \\
\hline
\end{tabular}



Figs. 1-2. 1: Pars intermedia cell from isolated control mouse. Note abundant secretory granules. $\times 6,800$. 2: Pars intermedia cell from sucking mouse. Note extension of Golgi complex and short cisternal profiles of r-ER. $\times 6,800$. 
Golgi area in sucking pups was evaluated after a reduction of each Golgi area (by $34 \%$ ).

In sucking pups, there was a significant increase both in the \% r-ER $(19.5 \%-$ $42.0 \%$ ) and the number of Golgi granules (1.2-2.1) and a significant decrease in the numerical density of secretory granules (2.9-1.6) compared to those of the isolation controls (Figs. 1 and 2; Table I).

Discussion. The results of the present studies demonstrate that the inhibitory control over the pars intermedia developes by the end of the first postnatal week in the mouse. In 7-day-old pups, the morphometric electron microscopy apparently revealed a cytological sign of hypofunction in cells of the pars intermedia, i.e. (1) a decline in the $\% \mathrm{r}$-ER indicative of a suppression of protein synthesis, (2) a decrease in number of Golgi granules per unit Golgi area showing a reduction of the granule-forming activity and (3) an increase in numerical density of secretory granules reflecting a release inhibition of secretory granules (Table I). These results are in harmoney with previous studies demonstrating the adult pattern of nerve supply to the pars intermedia achieved by 7 days of postnatal life in the mouse (Jarskär, 1977) and an increase in $\alpha$-MSH concentrations in the mouse pituitary during the first postnatal week which is accounted for by the onset of inhibitory control by dopaminergic innervation (Schmitt et al., 1981).

The present studies also provide evidence that sucking after a brief separation of pups from their mother stimulated the secretory activity of the pars intermedia of the pups at 7 days of age. Significant rise in the $\%$ r-ER and the Golgi granule formation accompanied by a decrease in number of secretory granules are distinct sign of hyperfunction of the pars intermedia.

Our previous morphometric studies suggested, for the first time, an involvement of the pars intermedia in the control mechanism of aldosterone production in sodium-depleted mice (Kobayashi, 1974; Kobayashi and Takema, 1976; Kobayashi, 1977). This finding has recently been confirmed by in vitro studies. Aldosterone secretion is enhanced by $\alpha$-MSH (Vinson et al., 1981) and $\beta$-MSH (Yamakado et al., 1983) at physiological concentrations in isolated zona glomerulosa cells from sodium-depleted rats and by $\gamma$-MSH (Schiffrin et al., 1983) in cells from a hypertensive patient with primary hyperaldosteronism. However, both dietary sodium-depletion and hypertension associated with hyperaldosteronism appear to be the conditions far from normal. Accordingly, the results of these experiments are of little use for understanding of the physiological role of MSHs in murines. In this connection sucking may be a relevant condition to explore the functional significance of MSHs in mammals. Satiation with milk after mild fasting naturally induces the intake of a large amount of water in pups resulting in the activation of the pars intermedia. Excessive water intake induced by free access to a $5 \%$ glucose solution in mice after fooddeprivation has been proved to be a very potent stimulus for the pars intermedia (Kobayashi et al., 1984). It is of interest to investigate an involvement of the pars intermedia in hydromineral regulation of the sucking infant. Detailed studies of age-related time-course of the pars intermedia function in sucking mice are now in progress.

Summary. Ultrastructural morphometric studies have showed that the inhibitory control mechanism over the pars intermedia developed by the end of the first postnatal week, and provided new evidence that sucking after mild fasting is a potent stimulus to enhance the activity of the pars intermedia in young mice. 


\section{References}

1) Björklund, A., Enemar, A., and Falk, B. (1968): Z. Zellforsch. Mikrosk. Anat., 89, 590-607.

2) Björklund, A. et al. (1973) : Brain Res., 53, 274-292.

3) Etkin, W. (1962): Gen. Comp. Endocrinol., suppl., 11, 148-159.

4) Jarskär, R. (1977) : Cell Tiss. Res., 184, 121-132.

5) Kobayashi, Y. (1974) : ibid., 154, 321-327.

6) - (1977): Gunma Symp. Endocrinol., 14, 61-74.

7) Kobayashi, Y., and Takema, M. (1976) : Cell Tiss. Res., 168, 153-159.

8) Kobayashi, Y., Kumazawa, T., and Takeuchi, M. (1984) : Arch. Histol. Jap., 47, $71-77$.

9) Schiffrin, E. L. et al. (1983) : Horm. Metabol. Res., 15, 181-184.

10) Schmitt, G., Stoeckel, M. E., and Koch, B. (1981): Neuroendocrinology, 33, 306-311.

11) Tilders, F. J. H., Mulder, A. H., and Smelik, P. G. (1975) : ibid., 18, 125-130.

12) Vinson, G. P., Whitehouse, B. J., and Thody, A. J. (1981): Peptides, 2, 141-144.

13) Yamakado, M., Franco-Saenz, R., and Mulrow, P. J. (1983) : Endocrinology, 113, $2168-2172$. 